American Journal of Agricultural and Biological Sciences 5 (3): 309-314, 2010

ISSN 1557-4989

(C) 2010 Science Publications

\title{
Estimation of Genetic Correlations on Sweet Corn Inbred Lines Using SAS Mixed Model
}

\author{
Pedram Kashiani and Ghizan Saleh \\ Department of Crop Science, Faculty of Agriculture, \\ University Putra Malaysia, 43400 Serdang, Selangor, Malaysia
}

\begin{abstract}
Problem statement: Genetic correlations among traits refer to the extent of relatedness among them due to genetic causes. Estimating genetic correlations for quantitative traits is tedious if done manually. Approach: However, the use of the computer software SAS, applying mixed-model analysis of variance has facilitated many recent studies in evolutionary quantitative genetics. Results: In this two-way statistical model, the variance component corresponding to the random statement is the covariance associated with a level of the random factor across levels of the fix factor. Therefore, the SAS model has a natural application for estimating genetic correlations among traits measured. Correlation studies were undertaken for 10 yield-related traits on a series of near-homozygous sweet corn inbred lines obtained from various tropical source populations. The SAS program was used to estimate genetic correlation coefficients among traits observed, where effects of blocks were considered fixed while effects of inbred lines as random. The "ASYCOV" was added to the "PROC MIXED" statement in order to produce the variance-covariance matrix of variance components. The "TYPE = UN" option requested in "RANDOM" statement resulted in an unstructured covariance matrix for each inbred line being estimated, while the "G" and "GCORR" options produced genetic variance-covariance matrix and genetic correlation matrix between traits, respectively. Results showed that there was no significant difference between genetic correlations estimated by SAS MIXED model and those estimated by manual calculation. Conclusion/Recommendations: This indicated that SAS has the natural capability to estimate genetic correlations among traits measured, as opposed to manual methods employing quantitative genetics equations.
\end{abstract}

Key words: Genetic correlation, SAS, proc mixed model, inbred line, sweet corn

\section{INTRODUCTION}

Crop yield is a complex character controlled by several interacting genotypic and environmental factors. There are yield components which are less complex, highly inherited and less influenced by the environmental deviations. Hence, Grafius (1956) suggested that selection based on the highly inherited components which are significantly related to yield is more effective than selection of yield per se. The interrelationships existed between yield and its contributing components can significantly improve the efficiency of crop breeding programmes through the use of proper selection indices (Mohammadi et al., 2003; Kashiani et al., 2010). Direct selection for yield is often deceptive as it is highly influenced by fluctuating environmental components (Talebi et al., 2007). The correlation coefficient analysis is useful in the selection of several traits simultaneously influencing yield
(Menkir, 2008). Genetic correlation analysis exploits the degree of association among important quantitative traits (Malik et al., 2005). By utilizing genetic correlations between traits, secondary traits can be used to improve primary ones that have low heritability or are difficult to measure (Malosetti et al., 2008). Manual calculation of genetic correlations is difficult since investigators have to calculate variance components for each character and covariance between any pair of characters taken in the experiment to obtain genetic variance and covariance values which are mandatory components to calculate genetic correlations. The SAS documentation is formidable, however and coming up with the appropriate "MIXED" statements for estimating parameters like genetic correlations is a daunting task for the uninitiated (Delwiche and Slaughter, 2008).

Mixed-model methods primarily use three approaches to variance component estimation: (1) procedures based on expected mean squares from the

Corresponding Author: Ghizan Saleh, Department of Crop Science, Faculty of Agriculture, University Putra Malaysia, 43400 Serdang, Selangor, Malaysia 
Analysis Of Variance (ANOVA); (2) Maximum Likelihood (ML) and (3) Restricted Maximum Likelihood (REML), also known as residual maximum likelihood (Jun, 2000). Of these, the use of ML is usually discouraged, because the variance component estimates are biased downwards and hence so are the standard errors computed from them. This results in excessively narrow confidence intervals whose coverage rates are below the nominal 1- $\alpha$ level and upwardly biased test statistics, Type I error rates of which tend to be well above the nominal $\alpha$ level. The REML procedure is the most versatile method (Littell et al., 2006). REML estimates of variance components are unbiased by selection and assortative mating (Gianola and Fernando, 1986). "PROC MIXED" in SAS uses the REML approach by default, but provides optional use of other methods when needed. There are situations for which ANOVA procedures are preferable. By using the mixed model the response vector which is the result of random and fixed factors and covariables, a wide range of possible (co)variance structures can be used to model the data, improving tests and estimates of treatment effects (Malosetti et al., 2008).

\section{MATERIALS AND METHODS}

This study was an advanced stage of a long-term tropical sweet corn inbred line development programme conducted at University Putra Malaysia where a series of near-homozygous inbred lines obtained from various source populations were evaluated. The evaluation was carried out in a Randomized Complete Block Design (RCBD) with three replications. All inbred lines were of tropical origin namely Bakti-1-S $\mathrm{S}_{7}$, Manis Madu- $\mathrm{S}_{7}$, TSS Tin- $\mathrm{S}_{7}$, Mas Madu-S $\mathrm{S}_{6}$, Thailand- $\mathrm{S}_{6}$, Indonesia- $\mathrm{S}_{6}$, TSS Melaka- $S_{5}$, Manis Madu x Indonesia-S $\mathrm{S}_{4}$ and SBY$\mathrm{S}_{4}$. All experimental plots were subjected to uniform agronomic practices. Data were collected before and after harvest, which include days to tasselling, days to silking, plant height $(\mathrm{cm})$, number of ears per ha, fresh ear yield $\left(\mathrm{kg} \mathrm{ha}^{-1}\right)$, ear diameter $(\mathrm{mm})$, number of kernels per row, number of kernel rows per ear and Total Soluble Solids concentration (TSS) (\%).

Since for every inbred line, any given pair traits (X and $\mathrm{Y}$ ) were measured in different blocks, there could be environmental reasons for a relationship between $\mathrm{X}$ and $\mathrm{Y}$. Hence the environmental variance should be taken apart of phenotypic variance of any trait measured to obtain genotypic variance. Table 1 shows generalized expectations of mean squares of analysis of variance and covariance for two traits, $\mathrm{X}$ and $\mathrm{Y}$.

Genotypic variance of each trait is obtained by the variance components method suggested by Becker (1992) as follows:

$\sigma_{\mathrm{G}}^{2}=\frac{\left(\sigma_{\mathrm{BI}}^{2}+b{\sigma_{\mathrm{I}}^{2}}^{2}\right)-\sigma_{\mathrm{BI}}^{2}}{\mathrm{~b}}$

where, $\sigma_{\mathrm{G}}^{2}, \sigma_{\mathrm{I}}^{2}, \sigma_{\mathrm{BI}}^{2}$ and $\mathrm{b}$ are genotypic variance, variance for inbred lines, environmental variance and number of replications, respectively.

Genotypic covariance between the traits $\mathrm{X}$ and $\mathrm{Y}$ is also achieved as follows:

$$
\sigma_{\mathrm{G}}=\frac{\left(\sigma_{\mathrm{BI}(\mathrm{XY})}+\mathrm{b} \sigma_{\mathrm{I}(\mathrm{XY})}\right)-\sigma_{\mathrm{BI}(\mathrm{XY})}}{\mathrm{b}}
$$

where, $\sigma_{\mathrm{G}}, \sigma_{\mathrm{I}(\mathrm{XY})}, \sigma_{\mathrm{BI}}^{2}$ and $\mathrm{b}$ are genotypic covariance, covariance between trait $\mathrm{X}$ and $\mathrm{Y}$ caused by inbred lines, environmental covariance between $\mathrm{X}$ and $\mathrm{Y}$ and number of replications, respectively.

Correlation coefficient of $\mathrm{X}$ and $\mathrm{Y}$ is a measure of linear dependence between $\mathrm{X}$ and $\mathrm{Y}$ and can be explained by normalized covariance as follows:

$$
\rho=\frac{\sigma_{(X, Y)}}{\sqrt{\sigma_{1}^{2}, \sigma_{2}^{2}}}
$$

Where:

$\rho=$ Correlation coefficient between $X$ and $Y$

$\sigma_{(\mathrm{X}, \mathrm{Y})}=$ Covariance between $\mathrm{X}$ and $\mathrm{Y}$

$\sigma_{1}^{2}=$ Variance of $\mathrm{X}$

$\sigma_{2}^{2}=$ Variance of $Y$

The above equations of genetic variance and covariance and correlation coefficient suggest that the genetic correlation coefficient can also be estimated from the components of variance, as follows:

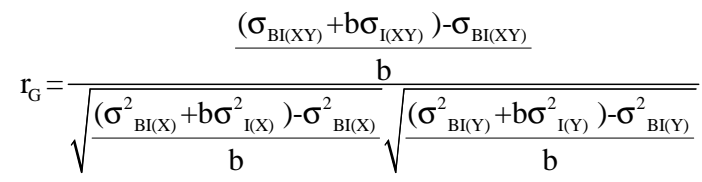

Table 1: Generalized expectations of mean squares of Analysis Of Variance (ANOVA) and Covariance (ANCOVA) for X and Y

\begin{tabular}{llll}
\hline Source & d.f. & $\mathrm{E}(\mathrm{MS})_{\mathrm{X}}$ & $\mathrm{E}(\mathrm{MS})_{\mathrm{Y}}$ \\
\hline Blocks & $(\mathrm{r}-1)$ & $\sigma_{\mathrm{BI}(\mathrm{X})}^{2}+\mathrm{i} \sigma_{\mathrm{B}(\mathrm{X})}^{2}$ & $\sigma_{\mathrm{BI}(\mathrm{Y})}+\mathrm{i} \sigma_{\mathrm{B}(\mathrm{Y})}^{2}$ \\
Inbred lines & $(\mathrm{t}-1)$ & $\sigma_{\mathrm{BI}(\mathrm{X})}^{2}+\mathrm{b} \sigma_{\mathrm{I}(\mathrm{X})}$ & $\sigma_{\mathrm{BI}_{(\mathrm{Y})}+\mathrm{b} \sigma_{\mathrm{I}(\mathrm{Y})}}$ \\
Blocks X inbred lines & $(\mathrm{r}-1)(\mathrm{t}-1)$ & $\sigma_{\mathrm{BI}(\mathrm{X})}^{2}$ & $\sigma_{\mathrm{BI}(\mathrm{XY})}^{2}+\mathrm{i} \sigma_{\mathrm{B}(\mathrm{XY})}^{2}$ \\
\hline
\end{tabular}


This is similar to the formula described by Falconer and Mackay (1996) as follows:

$$
\mathrm{r}_{\mathrm{G}}=\frac{\sigma_{\mathrm{G}(\mathrm{X}, \mathrm{Y})}}{\sqrt{\sigma_{\mathrm{G}(\mathrm{X})}^{2}, \sigma_{\mathrm{G}(\mathrm{Y})}^{2}}}
$$

Where:

$\mathrm{r}_{\mathrm{G}} \quad=$ Genetic correlation between the traits $\mathrm{X}$ and $\mathrm{Y}$

$\sigma_{\mathrm{G}(\mathrm{X}, \mathrm{Y})}=$ Genotypic covariance between the traits $\mathrm{X}$ and $\mathrm{Y}$

$\sigma_{G(X)}^{2}=$ Genotypic variance of the trait $X$

$\sigma_{\mathrm{G}(\mathrm{Y})}^{2}=$ Genotypic variance of the trait $\mathrm{Y}$

It is very clear that estimate of genetic correlation using the method described above is very difficult and time consuming. In contrast, the "MIXED" procedure in SAS is a highly flexible program that can be used for estimating genetic correlation by using REML to estimate genetic variance components in mixed-model approach (Littell et al., 1996). The mixed model applied to estimate genetic variance components from the nine inbred lines studied in three replications (environment), was:

$$
y=X \beta+Z \alpha+\varepsilon
$$

Where:

$\mathrm{y} \quad=$ The vector of $\mathrm{n}$ observations for each family (response vector)

$\mathrm{X}$ and $\beta=$ The design matrix and the vector of fix effects including replications and the means of each trait measured across inbred lines

$\mathrm{Z}$ and $\alpha=$ Design matrix assigning the random effects to the observations and the vector of random effects, respectively

$\varepsilon=$ The vector of non-genetic residuals associated with each observation and normally distributed, $\varepsilon \sim \mathrm{N}(0, \mathrm{R})$

Vector $\alpha(1 \leq \mathrm{d} \leq \infty)$ collects the random genotypic effects per trait, where d is number of "TRAIT" levels which is equal to number of traits measured in the experiment. Random genetic effects are assumed normally distributed, $\alpha \sim \mathrm{N}(0, \mathrm{G})$; With $\mathrm{G}$ the genetic (co)variance matrix.

The following program fits a mixed model to the data to estimate genetic correlation in this study:

proc mixed covtest asycov method $=\mathrm{reml}$; class rep gen trait; model y = trait rep;

repeated /type $=\mathrm{UN}$ sub $=$ rep*gen $\mathrm{r}$ rcorr; random trait /type $=$ un sub $=$ gen $g$ gcorr; run;

In this program "REP", "GEN" and "Y" variables are used to refer to replications, inbred lines and data taken from each experimental unit, respectively. The variable "TRAIT" is a dummy variable and differs from one trait measured to another. The fixed-effect-class (independent) variables including "TRAIT" and "REP" are listed after the dependent variable "Y". The variables "TRAIT", "GEN" and "GEN*REP" are considered as random. The option "COVTEST" was used to provide estimates of the standard errors of the estimated variance components. The "ASYCOV" was added to the "PROC MIXED" statement in order to produce the variance-covariance matrix of variance components since genetic correlation is a variancecovariance relationship of genotypic variance. The "CLASS" statement specifies that "REP", "GEN" and "TRAIT" are classification variables and not continuous variables.

The "REPEATED" statement is used to specify correlated error structures. The "TYPE $=\mathrm{UN}$ " option specifies the covariance structure as being of the unstructured type. Depending on the data, it is possible to fit different covariance structures, such as Compound Symmetry (CS) or Autoregressive (AR). The "SUB = REP*GEN" option specifies the unit within which observations are correlated, in this case the whole-plot experimental unit. The options " $R$ " and "RCORR" request listings of the covariance and correlation matrices, respectively, within a given "REP*GEN" unit.

The option "TYPE = UN" in the "RANDOM" statement specifies the covariance structure for a subject's random effects. The "TYPE $=$ UN" calls for an unstructured $(2 \times 2)$ covariance matrix comprising the genetic variance of the random slopes $\left(\sigma_{\mathrm{a}}^{2}\right)$, the genetic variance of the random intercepts $\left(\sigma_{b}^{2}\right)$ and their covariance $\left(\sigma_{\mathrm{ab}}\right)$, since the " $\mathrm{G}$ " option requests genetic covariance-variance matrix as follows:

$$
\mathrm{G}=\left[\begin{array}{cc}
\sigma_{\mathrm{a}}^{2} & \sigma_{\mathrm{ab}} \\
\sigma_{\mathrm{ab}} & \sigma_{\mathrm{b}}^{2}
\end{array}\right]
$$

The "SUB = GEN" option in the "RANDOM" statement specifies that the intercept and slope of one inbred line are independently distributed from the intercepts and slopes of other inbred lines. The effects "TRAIT" and "REP" in the "RANDOM" statement, 
together with the "SUB = GEN" option, instruct "PROC MIXED" to add a random intercept and a random "TRAIT" slope for each inbred line to the fixed effects part of the model. The fixed effects part consists of a fixed intercept (automatically included through the "MODEL" statement) and a fixed slope in "TRAIT". The "GCORR" option requests a printout of the genetic correlation coefficients among different levels of "TRAIT".

Experimental error $\left(\sigma_{\mathrm{e}}\right)$ in RCBD experiments is the interaction between blocks and treatments applied because of the cross-classified relationship of blocks and treatments. Observations within the same block from different treatments are correlated (Fry, 1992). The intraclass correlation is a measure of this correlation. Because variance components must be non-negative, variance component models implicitly assume that the intraclass correlation is non-negative. However, there is no conceptual reason why correlation among observations within the same whole-plot experimental unit must be non-negative. In fact, in many practical situations, there are interferences or competition effects among adjacent experimental units that manifest themselves in negative correlations.

\section{RESULTS}

Results showed that genetic correlation estimated between any two given traits using either manual calculation or SAS MIXED model procedure is approximately equivalent. Estimation of genetic correlation between days to tasseling and days to silking was randomly chosen to show the above statement. Mean values for the performance of the inbred lines for days to tasseling and silking and sum of products between these two traits are shown in Table 2.

Genetic variance and genetic covariance were achieved for each trait using Equations 1and 2, respectively. Genetic correlation was then estimated between traits by using Eq. 5 (Table 3).

Table 4 extracted from the SAS output shows error variance and covariance belonging to days to tasseling and days to silking. 1.427 is error covariance between days to tasseling and days to silking, while 2.175 is error variance for days to tasseling and 2.123 is error variance of days to silking. These values are reasonably equal to those obtained from manual calculation as shown in Table 2.

In the estimated $\mathrm{R}$ Correlation Matrix Table (Table 5), 0.664 is the error correlation between the two traits, which can also be obtained from Table 4 as:

$$
r(E)=\frac{1.427}{\sqrt{2.175 * 2.123}}
$$

Table 2: Mean values and sum of products for the performance of the inbred lines between days to tasseling and silking

Mean squares

\begin{tabular}{lcrrr} 
& & \multicolumn{2}{c}{ Mean squares } & \\
\cline { 2 - 4 } Source of variation & d.f. & \multicolumn{1}{l}{$\begin{array}{l}\text { Days to } \\
\text { tasseling }\end{array}$} & $\begin{array}{l}\text { Days to } \\
\text { silking }\end{array}$ & $\begin{array}{l}\text { Sum of } \\
\text { products }\end{array}$ \\
\hline Blocks & 2 & 8.955 & 14.065 & 11.215 \\
Inbred lines & 8 & 15.565 & 28.829 & 19.261 \\
Blocks X inbred lines & 16 & 2.204 & 2.148 & 1.401 \\
\hline
\end{tabular}

Table 3: Genetic variance, covariance and correlation for days to tasseling and silking

Genetic variance for days to tasseling $\quad 4.454$

Genetic variance for days to silking $\quad 8.894$

Genetic covariance between days to tasseling and silking $\quad 5.953$

Genetic correlation between days to tasseling and silking $\quad 0.946$

Table 4: Estimated R matrix obtained from SAS output

\begin{tabular}{lll}
\hline Row & Col1 (days to tasseling) & Col2 (days to silking) \\
\hline 1 (days to tasseling) & 2.175 & 1.427 \\
2 (days to silking) & 1.427 & 2.123 \\
\hline
\end{tabular}

Table 5: Estimated R correlation matrix obtained from SAS output

\begin{tabular}{lll}
\hline Row & Col1 (days to tasseling) & Col2 (days to silking) \\
\hline 1 (days to tasseling) & 1 & 0.664 \\
2 (days to silking) & 0.664 & 1 \\
\hline
\end{tabular}

Table 6: Estimated G matrix obtained from SAS output

\begin{tabular}{lllll}
\hline Row & Effect & Trait & Col1 & Col2 \\
\hline 1 & Trait & Silk & 8.902 & 5.945 \\
2 & Trait & Tassel & 5.945 & 4.463 \\
\hline
\end{tabular}

Table 7: Estimated G correlation matrix obtained from SAS output

\begin{tabular}{lllll}
\hline Row & Effect & Trait & Col1 & Col2 \\
\hline 1 & Trait & Silk & 1.0000 & 0.9431 \\
2 & Trait & Tassel & 0.9431 & 1.0000
\end{tabular}

The elements of the Estimated G Matrix shown in Table 6 are genetic variances and covariances for the two variables. 8.902 is the genetic variance for days to silking, 5.945 is the genetic covariance between the two traits and 4.463 is the genetic variance for days to tasseling. These values are reasonably equal to those calculated manually in Table 3 .

Finally by requesting "GCORR" option after the "RANDOM" statement, the code produces genetic correlation between the two traits (Table 7). Genetic correlation between days to tasseling and days to silking estimated through SAS PROC MIXED was 0.946, equal to what obtained from Equation 5. Genetic correlation can also be calculated using the Estimated $\mathrm{G}$ Matrix components as follows:

$$
r(G)=\frac{5.945}{\sqrt{8.902 * 4.463}}
$$


Am. J. Agri. \& Biol. Sci., 5 (3): 309-314, 2010

Table 8: Genetic correlation estimates obtained from SAS proc mixed model (S) and Manual calculation (M)

\begin{tabular}{|c|c|c|c|c|c|c|c|c|c|c|}
\hline & & $\begin{array}{l}\text { Husked } \\
\text { ear yield }\end{array}$ & $\begin{array}{l}\text { Dehusked } \\
\text { ear yield }\end{array}$ & $\begin{array}{l}\text { No. of } \\
\text { ears ha }\end{array}$ & $\begin{array}{l}\text { Plant } \\
\text { height }\end{array}$ & $\begin{array}{l}\text { Days to } \\
\text { tasselling }\end{array}$ & $\begin{array}{l}\text { Days to } \\
\text { silking }\end{array}$ & $\begin{array}{l}\text { Ear } \\
\text { diameter }\end{array}$ & $\begin{array}{l}\text { No. of } \\
\text { kernels/row }\end{array}$ & $\begin{array}{l}\text { No. of kernel } \\
\text { rows/ear }\end{array}$ \\
\hline Dehusked ear yield & $\begin{array}{l}\mathrm{M} \\
\mathrm{S}\end{array}$ & $0.962^{\text {** }}$ & & & & & & & & \\
\hline No. of ears ha ${ }^{-1}$ & $\begin{array}{l}M \\
S\end{array}$ & $0.914^{* *}$ & $\begin{array}{l}0.755^{* *} \\
0.817^{* *}\end{array}$ & & & & & & & \\
\hline Plant height & $\begin{array}{l}\mathrm{M} \\
\mathrm{S}\end{array}$ & $\begin{array}{l}0.949^{* * *} \\
0.967^{* *}\end{array}$ & $\begin{array}{l}0.971^{* *} \\
0.986^{* *}\end{array}$ & $\begin{array}{l}\text { NA } \\
\text { NA }\end{array}$ & & & & & & \\
\hline Days to tasselling & $\begin{array}{l}\mathrm{M} \\
\mathrm{S}\end{array}$ & $\begin{array}{l}-0.297^{\text {ns }} \\
-0.296^{\text {ns }}\end{array}$ & $\begin{array}{l}-0.570^{* *} \\
-0.570^{* *}\end{array}$ & $\begin{array}{l}0.086^{\text {ns }} \\
0.076^{\text {ns }}\end{array}$ & $\begin{array}{l}-0.322^{\text {ns }} \\
-0.302^{\text {ns }}\end{array}$ & & & & & \\
\hline Days to silking & $\begin{array}{l}M \\
S\end{array}$ & $\begin{array}{l}-0.508^{* *} \\
-0.508^{* * *}\end{array}$ & $\begin{array}{l}-0.732^{* *} \\
-0.732^{* *}\end{array}$ & $\begin{array}{l}0.108^{\mathrm{ns}} \\
0.094^{\mathrm{ns}}\end{array}$ & $\begin{array}{l}-0.366^{\text {ns }} \\
-0.346^{\text {ns }}\end{array}$ & $\begin{array}{l}0.946^{* *} \\
0.941^{* *}\end{array}$ & & & & \\
\hline Ear diameter & $\begin{array}{l}M \\
S\end{array}$ & $\begin{array}{l}0.752^{* *} \\
0.740^{* *}\end{array}$ & $\begin{array}{l}0.768^{* *} \\
0.753^{* *}\end{array}$ & $\begin{array}{l}0.758^{* *} \\
0.774^{* *}\end{array}$ & $\begin{array}{l}0.494^{*} \\
0.508^{* *}\end{array}$ & $\begin{array}{l}-0.564^{* * *} \\
-0.564^{* *}\end{array}$ & $\begin{array}{l}-0.640^{* * *} \\
-0.638^{* *}\end{array}$ & & & \\
\hline No. of kernels/row & $\begin{array}{l}\mathrm{M} \\
\mathrm{S}\end{array}$ & $\begin{array}{l}0.569^{* *} \\
0.582^{* *}\end{array}$ & $\begin{array}{l}0.832^{* *} \\
0.839^{* *}\end{array}$ & $\begin{array}{l}0.317^{\text {ns }} \\
0.337^{\text {ns }}\end{array}$ & $\begin{array}{l}0.796^{* *} \\
0.813^{* *}\end{array}$ & $\begin{array}{l}-0.494^{*} \\
-0.495^{*}\end{array}$ & $\begin{array}{l}-0.485^{*} \\
-0.486^{*}\end{array}$ & $\begin{array}{l}0.500^{* *} \\
0.458^{*}\end{array}$ & & \\
\hline No. of kernel rows/ear & $\begin{array}{r}\mathrm{M} \\
\mathrm{S}\end{array}$ & $\begin{array}{l}0.914^{* * *} \\
0.9066^{* *}\end{array}$ & $\begin{array}{l}\mathrm{NA} \\
\mathrm{NA}\end{array}$ & $\begin{array}{l}0.461^{*} \\
0.544^{* *}\end{array}$ & $\begin{array}{l}0.703^{* * *} \\
0.689^{* *}\end{array}$ & $\begin{array}{l}-0.509^{* *} \\
-0.503^{* *}\end{array}$ & $\begin{array}{l}-0.657^{* * *} \\
-0.659^{* *}\end{array}$ & $\begin{array}{l}0.927^{* *} \\
0.912^{* *}\end{array}$ & $\begin{array}{l}0.726^{* *} \\
0.731^{* *}\end{array}$ & \\
\hline TSS & $\begin{array}{l}M \\
S\end{array}$ & $\begin{array}{l}-0.414^{\mathrm{ns}} \\
-0.422^{\mathrm{ns}}\end{array}$ & $\begin{array}{l}-0.522^{* *} \\
-0.532^{* *}\end{array}$ & $\begin{array}{l}-0.378^{\text {ns }} \\
-0.373^{\text {ns }}\end{array}$ & $\begin{array}{l}-0.518^{* * *} \\
-0.517^{* *}\end{array}$ & $\begin{array}{l}-0.445^{*} \\
-0.446^{*}\end{array}$ & $\begin{array}{l}-0.293^{\text {ns }} \\
-0.293^{\text {ns }}\end{array}$ & $\begin{array}{l}0.159^{\text {ns }} \\
0.144^{\text {ns }}\end{array}$ & $\begin{array}{l}-0.686^{* *} \\
-0.692^{* *}\end{array}$ & $\begin{array}{l}-0.81^{* *} \\
-0.55^{* *}\end{array}$ \\
\hline
\end{tabular}

NA: Not Available

The difference existed between the genetic correlations obtained via these two methods was statistically tested using Paired Sample T-test. The result showed that there is no significant difference between genetic correlation values obtained from manual calculation and SAS PROC MIXED $(\mathrm{T}$ value $=$ 0.25, $\operatorname{Pr}>\mathrm{t}=0.802)$. This indicates that genetic correlation can be estimated correctly using SAS PROC MIXED which is a simple and fast procedure. Genetic correlations estimated through the manual calculation and SAS PROC MIXED MODEL is shown in Table 8.

The genetic correlation values obtained from this study were similar to those reported in previous investigations. Husked ear yield was found to have the highest positive genetic correlation with number of ears per ha $(r=0.99)$. Similar result reported by Martin and Russell (1984) and Wang et al. (1999) indicated that number of ears per ha was strongly and genetically associated with yield. Plant height, dehusked ear yield, number of kernel rows per ear, ear diameter and number of kernels per row were found to be positively genetically correlated with husked ear yield ( $\mathrm{r}=0.97$, $0.96,0.91,0.74$ and 0.58 , respectively). Plant height was reported to be strongly associated with grain yield (Akanvou et al., 1997; Kashiani et al., 2010; Martin and Russell, 1984; Burak and Magoja, 1991). Ear diameter was indicated to also have positive genetic correlation with grain yield by Burak and Magoja (1991); Kashiani et al. (2010); Malvar et al. (1994) and Xie et al. (2010). Numbers of kernels per row and kernel rows per ear have also a positive genetic correlation with grain yield (Kashiani et al., 2010; Liu, 2009; Wang et al., 1999; Xie et al., 2010; Yousuf and Saleem, 2001). Total soluble solids concentration and days to silking were found to be negatively correlated with husked fresh yield ( -0.52 and -0.51 , respectively).

\section{DISCUSSION}

The non-significant difference between the genetic correlation values estimated through manual calculation and the SAS programme indicates that genetic correlation can be estimated precisely using SAS PROC MIXED model which is a simple and fast procedure. Nevertheless, it should be concerned that if the computer used has limited random-access memory, SAS may fail to produce a correct result in situation where genetic correlations for many traits investigated simultaneously. To protect from this failure, the convergence criteria under the Iteration History of SAS output has to be met before execution of the analysis.

Number of ears per ha, plant height, number of kernel rows per ear, ear diameter and number of days to silking that showed highly interrelationship with husked fresh ear yield revealed that they were under the influence of certain common genes with husked fresh ear yield, thus could be exploited as selection criteria in breeding programs. Husked fresh yield could be efficiently increased by increasing number of ears per ha, plant height, number of kernel rows per ear and ear diameter, while reducing the number of days to silking among inbred lines.

\section{CONCLUSION}

SAS PROC MIXED model can be effectively used as a rapid approach assisting breeders to estimate genetic correlations in populations for further selection per purpose. From this study of genetic correlation, it has been revealed that husked fresh ear yield in these inbred line populations investigated could be improved through improvement in number of ears per ha, plant height, number of kernel rows per ear and ear diameter. 


\section{REFERENCES}

Akanvou, L., E.V. Doku and J. Kling, 1997. Estimates of genetic variances and interrelationships of traits associated with Striga resistance in maize. African Afr. Crop Sci. J., 5: 1-8. http://www.bioline.org.br/request?cs97001

Becker, W.A., 1992. Manual of Quantitative Genetics. 5th Edn., Academic Enterprises, Pullman, Washington, USA., ISBN: 10: 0931399114, pp: 191.

Burak, R. and J.L. Magoja, 1991. Yield and yield components of full-sib and half-sib families derived from a perennial teosinte introgression population. Maize Genet . Cooperat. Newslett., 65: 67-76. http://www.agron.missouri.edu/mnl/65/

Delwiche, L. and S. Slaughter, 2008. The Little SAS Book: A Primer. 4th Edn., SAS Institute Inc., Cary, NC., USA., ISBN: 978-1-59994-725-9, pp: 376.

Falconer, D.S. and T.F.C. Mackay, 1996. Introduction to Quantitative Genetics. 4th Edn., Benjamin Cummings, Longman Inc., New York, ISBN: 10: 0582243025, pp: 480.

Fry, J.D., 1992. The mixed-model analysis of variance applied to quantitative genetics: Biological meaning of the parameters. Evolution, 46: 540-550. http://www.jstor.org/pss/2409870

Gianola, D. and R.L. Fernando, 1986. Random-effects models for binary responses. Biometrics, 42: 217-218. PMID: 3719059

Grafius, J.E., 1956. Components of yield in oats: A geometrical interpretation. Agron. J., 48: 419-423. http://agron.scijournals.org/cgi/content/abstract/48/ 9/419

Jun, Z., 2000. Mixed linear model approaches for analyzing genetic models of complex quantitative traits. J. Zhej. Univ. Sci., 1: 78-90. DOI: 10.1007/BF02841054

Kashiani, P., G. Saleh, N.A.P. Abdullah and S.N. Abdullah, 2010. Variation and genetic studies on selected sweet corn inbred lines. Asian J. Crop Sci., 2: 78-84. DOI: 10.3923/ajcs.2010.78.84

Littell, R.C., G.A. Milliken, W.W. Stroup and R. Wolfinger, 1996. SAS System for Mixed Models. Illustrated Edn., SAS Institute Inc., Cary, NC., USA., ISBN: 10: 1555447791 , pp: 656.

Littell, R.C., A. George Milliken, W.W. Stroup, R.D. Wolfinger and O. Schabenberger, 2006. SAS for Mixed Models. 2nd Edn., SAS Publishing, Cary, NC., USA., ISBN: 13: 978-1590475003, pp: 840.

Liu, W., 2009. Correlation between specific fine root length and mycorrhizal colonization of maize in different soil types. Front. Agric. China 3: 13-15. DOI: $10.1007 / \mathrm{s} 11703-009-0004-3$
Malik, H.N., S.I. Malik, M. Hussain, S.U.R. Chughtai and H.I. Javad, 2005. Genetic correlation among various quantitative characters in maize (Zea mays L.) hybrids. J. Agric. Soc. Sci., 1: 262-265. http://www.fspublishers.org/jass/pastissues/JASSVOL_1_NO_3/14.pdf

Malosetti, M., J. Ribaut, M. Vargas, J. Crossa and F. Van Eeuwijk, 2008. A multi-trait multienvironment QTL mixed model with an application to drought and nitrogen stress trials in maize (Zea mays L.). Euphytica, 161: 241-257. DOI: $10.1007 / \mathrm{s} 10681-007-9594-0$

Malvar, R.A., P. Revilla and A. Ordas, 1994. Additive correlation between days to flowering and agronomic traits in low land races of maize. Ann. Estac. Exp. Aula Dei, 20: 59-64. http://digital.csic.es/handle/10261/4062

Menkir, A., 2008. Genetic variation for grain mineral content in tropical-adapted maize inbred lines. Food Chem., 110: 454-464. DOI: 10.1016/j.foodchem.2008.02.025

Martin, M.J. and W.A. Russell, 1984. Correlated responses of yield and other agronomic traits to recurrent selection for stalk quality in a maize synthetic. Crop Sci., 24: 746-750. http://crop.scijournals.org/cgi/content/abstract/24/4 1746

Mohammadi, S.A., B.M. Prasanna and N.N. Singh, 2003. Sequential path model for determining interrelationships among grain yield and related characters in maize. Crop Sci., 43: 1690-1697. http://crop.scijournals.org/cgi/content/abstract/43/5 $/ 1690$

Talebi, R., F. F. and N.A. Babaeian Jelodar, 2007. Correlation and path coefficient analysis of yield and yield components of chickpea (Cicer arietinum L.) under dry land condition in the West of Iran. Asian J. Plant Sci. 6: 1151-1154. DOI: 10.3923/ajps.2007.1151.1154

Wang, G., M.S. Kang and O. Moreno, 1999. Genetic analyses of grain-filling rate and duration in maize. Field Crops Res., 61: 211-222. DOI: 10.1016/S0378-4290(98)00163-4

Xie, H., D. Ding, Z. Cui, X. Wu and Y. Hu et al., 2010. Genetic analysis of the related traits of flowering and silk for hybrid seed production in maize. Genes Genom., 32: 55-61. DOI: 10.1007/s13258-0100801-3

Yousuf, M. and M. Saleem, 2001. Correlation Analysis of S1 Families of Maize for Grain Yield and its Components. Int. J. Agric. Biol., 3: 387-388. http://www.fspublishers.org/ijab/pastissues/IJABVOL_3_NO_4/13.pdf 